\title{
Pendampingan Guru Dalam Penggunaan Alat Permainan Edukatif Berbasis Enam Aspek Perkembangan Anak Di TK Salsa
}

Received : 22 Oktober 2021

Revised : 2 November 2021

Accepted : 5 November 2021

\author{
Anada Leo Virganta ${ }^{1}$, Kamtini ${ }^{2}$, Dwi Maya Novitri ${ }^{3}$ \\ 1,2,3 Program Studi PG PAUD FIP \\ Universitas Negeri Medan \\ E-mail : anadaleovirganta@unimed.ac.id
}

\begin{abstract}
Abstrak: Pendidikan yang bermutu memerlukan guru yang memahami kebutuhan anak usia dini untuk mencapai tingkat pencapaian perkembangan yang sesuai dengan usianya. Disamping guru yang bermutu, diperlukan pula pembelajaran yang menarik bagi anak melalui benda-benda yang hadir secara kongkrit ditengah-tengah anak. Tujuan pengabdian ini adalah untuk memberikan pendampingan bagi guru-guru di TK Salsa dalam penggunaan alat permainan edukatif (APE) sesuai untuk menstimulus enam aspek perkembangan dan menyusun asesmen perkembangan anak usia dini. Metode pelaksanaan kegiatan pengabdian dilakukan secara bertahap dan berkelanjutan dan komprehensif melalui kegiatan pendampingan berkelanjutan dan simulasi APE Magic BABO bebrbasis enam aspek perkembangan anak usia dini. APE yang digunakan diberi nama Magic BABO (Balok Book). Hasil pendampingan ini bersifat moril berupa peningkatan keterampilan guru dalam menggunakan APE Magic BABO, peningkatan pengetehuan guru dalam menyusun asesmen berbasis enam asperk perkembangan anak, hasil yang bersifat fisik adalah adanya APE Magic BABO bebrbasis enam aspek perkembangan anak usia dini yang dapat digunakan oleh guru di dalam pelaksanaan pembelajaran.
\end{abstract}

Kata kunci: Pendampingan, $A P E$ Magic $B A B O$, Asesmen

\section{PENDAHULUAN}

Undang-undang Republik Indonesia No. 20 Tahun 2003 tentang Sistem Pendidikan Nasional Bab 1 Pasal I Ayat I dinyatakan bahwa pendidikan adalah usaha sadar dan terencana untuk mewujudkan suasana belajar dan proses pembelajaran agar peserta didik secara aktif mengembangkan potensi dirinya untuk memiliki kekuatan spiritual keagamaan, pengendalian diri, kepribadian, kecerdasan, akhlakmulia, serta keterampilan yang diperlukan dirinya, masyarakat, bangsa dan negara.

Dalam Kepmendikbud No. 0486/U/1992 BAB II Pasal 3 Ayat 1 dinyatakan bahwa tujuan penyelenggaraan TK adalah membantu meletakan dasar ke arah perkembangan sikap, perilaku, pengetahuan, keterampilan, dan daya cipta anak didik untuk pertumbuhan serta perkembangan selanjutnya. Menciptakan pendidikan yang bermutu diperlukan guru yang memahami kebutuhan anak usia dini untuk mencapai tingkat pencapaian perkembangan yang sesuai dengan usianya. Disamping guru yang bermutu, diperlukan pula pembelajaran yang menarik bagi anak melalui benda-benda yang hadir secara kongkrit ditengah-tengah anak. 
Pendidikan bagi anak usia dini merupakan pendidikan yang menyenangkan dengan prinsip belajar melalui bermain . Kegiatan bermain yang dilakukan anak-anak ketika berada di sekolah juga terbukti menjadi salah satu faktor yang dapat mengoptimalkan perkembangan literasi anak-anak (Pyle et al., 2018). Menurut Soetjiningsih, (2012: 221) salah satu karakteristik bermain adalah bermain dilakukan secara sukarela tanpa paksaan, selalu menyenangkan, menimbulkan kegembiraan atau kenikmatan, dan merangsang perilaku lain. Ketika sedang melakukan aktivitas bermain, anak sedang mengungkapkan pemikiran, keinginan, perasaan, menjalin hubungan sosial dengan lingkungannya dan mengembangkan kemampuan sosial, kognitif, spiritual, moral dan emosionalnya secara bersamaan. Dengan proses bermain, pembelajaran akan menjadi lebih menyenangkan, menarik, mudah diikuti dan dipahami oleh anak. Untuk mendukung anak mengembangkan kemampuannya, guru harus dapat menyediakan alat permainan edkutif yang tepat.

Anak usia dini merupakan masa peka dalam berbagai aspek perkembangan yaitu masa awal pengembangan kemampuan fisik motorik, bahasa, sosial emosional, serta kognitif. Anak berkembang dengan sangat pesat sehingga pengumpulan data instrumen perkembangan anak lebih banyak menggunakan teknik observasi yang lebih menekankan pada proses, individual dan bersifat kualitatif. Tujuanya adalah untuk membantu/ mengetahui perkembangan anak secara umum dalam pengasuhan, berpikir dan tingkat kepercayaannya.

Asesmen pembelajaran dalam proses pendidikan merupakan komponen yang tidak dapat dipisahkan dari komponen lainnya dalam kegiatan belajar mengajar di kelas. Lara Firdani (2011) menyatakan bahwa asesmen yaitu proses pengumpulan data dengan berbagai cara tentang aspek perkembangan dan indikator kemampuan yang harus dicapai sesuai dengan tahap perkembangan anak. Asesmen pada anak usia dini tidak hanya bertujuan untuk mengetahui sejauh mana anak tumbuh dan berkembang. Tapi juga akan membantu guru dalam menentukan penyelesaian masalah perkembangan dan pembelajaran.

Hasil observasi yang dilakukan di TK Salsa Desa Cinta Rakyat Kecamatan Percut Sei Tuan Deli Serdang ditemukan permasalahan pokok yang menjadi acuan utama dalam pengabdian yaitu kenyataan yang dihadapi di lapangan, guru belum menerpkan penggunaan media ataupun Alat Permainan Edukatif (APE) disetiap proses pembelajaran. Hal tersebut menjadikan pembelajaran lebih bersifat akademistis dan tidak dilakukan seraya bermain, dengan mengedepankan membaca, menulis dan berhitung untuk mempersiapkan anak menuju jenjang sekolah dasar. Dengan kata lain pembelajaran yang dilakukan belum menggunakan pendekatan bermain, penggunaan media pembelajaran yang masih besifat abstrak, proses pembelajaran masih bersifat akademis yang menekankan pada membaca, menulis dan berhitung, sehingga kurangnya penggunaan APE dalam proses pembelajaran.

Beberapa kendala yang menjadi penyebab permasalahan tersebut di atas adalah tidak semua guru memperoleh pengetahuan dan pemahaman yang sama tentang membuat dan menggunakan media APE. Keterbatasan jumlah guru yang dapat dikirim untuk mengikuti pelatihan di tingkat kabupaten menjadikan ketidakseimbangan pengetahuan dan pemahaman guru-guru di TK Salsa Desa Cinta Rakyat Kecamatan Percut Sei Tuan Deli Serdang terhadap Penggunaan APE serta asesmen yang sesuai.

Dalam hal lain, sekolah tidak memiliki cukup dana untuk mengadakan pendampingan secara khusus bagi guru-guru agar permasalahan ini dapat teratasi. Atas dasar inilah, tim 
pengabdi merasa sangat perlu untuk melaksanakan Pendampingan Penggunaan APE Magic BABO (Balok Book) Pada Guru TK Salsa Desa Cinta Rakyat Kecamatan Percut Sei Tuan Kabupaten Deli Serdang. Melalui kegiatan ini, akan dilaksanakan pendampingan bagi guru-guru untuk menggunakan media APE Magic BABO dan melakukan asesmen yang sesuai.

\section{METODE}

Pendampingan penggunaan alat permainan edukatif dilaksankan diTK Salsa berada di jalan Siliwagni No.25 Desa Cinta Rakyat Kecamatan Percut Sei Tuan Kabupaten Deli Serdang Sumatera Utara. kegiatan tersebut dilaksanakan dalam beberapa tahap, yaitu tahap persiapan, Pelaksanaan pendampingan, simulasi, dan evaluasi.

Pada tahap persiapan,tim pengabdi mengadakan observasi awal ke sekolah mitra, membuat kesepakatan mekanisme pelatihan dan pendampingan, membuat modul dan instrumen pendampingan guru dalam penggunaan alat permainan edukatif berbasis enam aspek perkembangan anak di Tk Salsa Desa Cinta Rakyat Kecamatan Percut Sei Tuan Deli Serdang

Pelaksanaan kegiatan Pendampingan guru dalam penggunaan APE Magic BABO dilakukan dalam 2 hari yaitu Pelaksanaan Workshop di hari pertama dengan penyampaian materi pendampingan guru dalam penggunaan alat permainan edukatif berbasis enam aspek perkembangan anak. Pelaksanaan Workshop di hari kedua dengan kegiatan pendampingan penyusunan asesmen pembelajaran anak usia dini.

Simulasi penggunaan APE Magic BABO dilakukan oleh 3 orang guru telah ditentukan untuk melakukan Real Teaching di dalam kelasnyaa masing-masing sebagai implementasi penggunaan media alat permainan anak.. Tim pengabdi juga memberikan sedikit pemahaman tentang asesmen terhadap anak. Kemudian para guru mengisi asesmen tersebut sesuai dengan kemampuan anak setelah bermain "Magic Babo".

Metode pendekatan dilakukan berdasarkan permasalahan dan target capaian setiap kegiatan. Beberapa pendekatan yang akan digunakan dalam kegiatan ini adalah pendampingan, simulasi pembelajaran. Setiap pendekatan dilakukan berdasarkan tujuan kegiatan yang ingin dicapai.

\section{HASIL DAN DISKUSI}

Persiapan kegiatan pengabdian ini dilakukan mulai bulan Juni 2021, dengan beberapa rangkaian kegiatan sebagai berikut: Pertemuan tim pengabdi dengan kepala sekolah dan duru-duru TK SALSA secara tatap muka dengan tetap mematuhi protocol kesehatan. Melalui pertemuan ini diperoleh hasil fokus masalah guru yang akan diselesaikan yaitu mendampingi guru dalam penggunaan alat permainan edukatif berbasis enam aspek perkembangan anak dan membuat asesmen untuk anak. Persiapan dokumen/surat izin dari LPPM Unimed untuk proses pelaksanaan pengabdian. Penyusunan jadwal pertemuan.

Pelaksanaan kegiatan pengabdian kepada masyarakat ini difokuskan pada pendampingan guru dalam penggunaan alat permainan edukatif berbasis enam aspek perkembangan anak serta pendampingan dalam pengisian asesmen untuk anak.

Pendampingan diawali dengan pemaparan materi sekaligus pembukaan kegiatan yang dilakukan pada tanggal 6 Agustus 2021 di ruang tamu TK Salsa. Kegiatan ini dihadiri 
oleh 12 Guru TK Salsa yang mewakili dari setiap kelas pagi dan kelas siang. Pada kegiatan ini tim pengabdi memaparkan tentang materi tentang manfaat penggunaan alat permainan eduktif dalam pembelajaran serta pentingnya kemampunan guru dalam memberikan asesmen perkembangan anak.

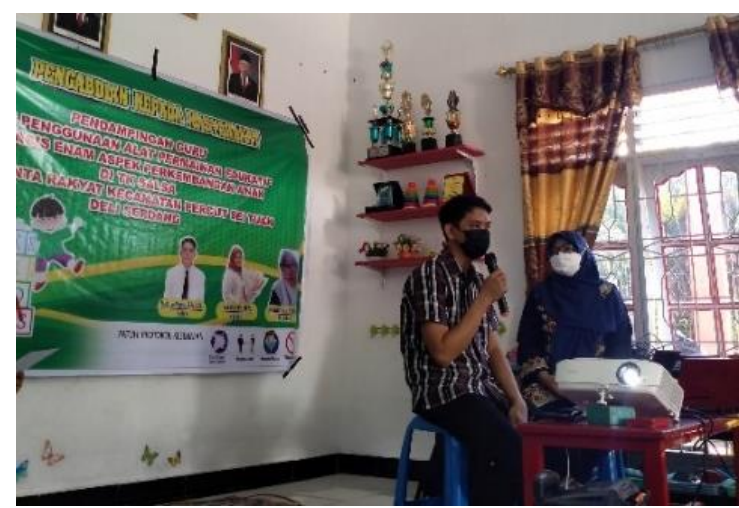

Gambar 1. Penyampaian materi penggunaan alat permainan edukatif dan asesmen

Selanjutnya penyampaian materi tentang penggunaan media alat permainan edukatif berbasis enam aspek perkembangan anak kepada guru-guru di Tk Salsa. Materi penggunaan media alat permainan edukatif berbasis enam aspek perkembangan anak berisikan tentang bagaimana penggunaan alat permainan edukatif serta hubungan alat permainan edukatif terhadap enam aspek perkembangan anak. Pemberian materi ini bertujuan agar guru-guru di TK Salsa dapat memahami terhadap alat permainan edukatif serta memahami cara mengembangkan keenam aspek perkembangan anak dengan menggunakan alat permainan edukatif.

Melalui pemaparan materi yang disampaikan oleh tim pengabdi, guru-guru di TK Salsa juga didampingi oleh tim pengabdi dalam menjalankan atau penggunaan alat permainan edukatif kepada anak-anak. Melalui kegiatan ini guru-guru di TK Salsa dapat memahami cara penggunaan alat permainan edukatif berbasis enam aspek perkembangan anak.

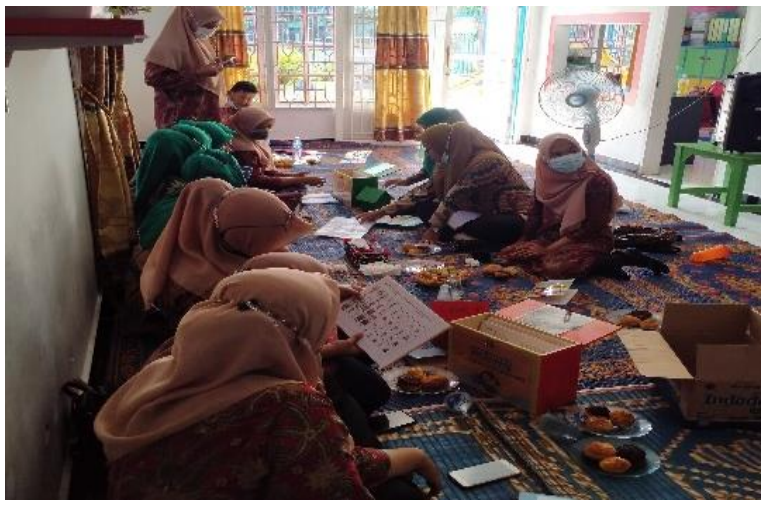

Gambar 2. Pendampingan Pengunaan APE

Pelaksanaan pendampingan penyusunan asesmen dilakukan pada tanggal 7 Agustus 2021 di ruang tamu TK Salsa. Kegiatan ini dihadiri oleh 3 Guru TK Salsa yang sebelumnya telah mengikuti workshop/pendampingan dalam penggunan APE Magic Babo. Guru-guru tersebut telah ditentukan untuk melakukan Real Teaching di dalam kelas sebagai implementasi penggunaan media alat permainan anak. Pada kegiatan ini diberikan pemaparan materi tentang asesmen perkembangan anak melalui penggunaan media alat 
permainan edukatif berbasis enam aspek perkembangan anak oleh tim pengabdi kepada guru-guru di Tk Salsa.

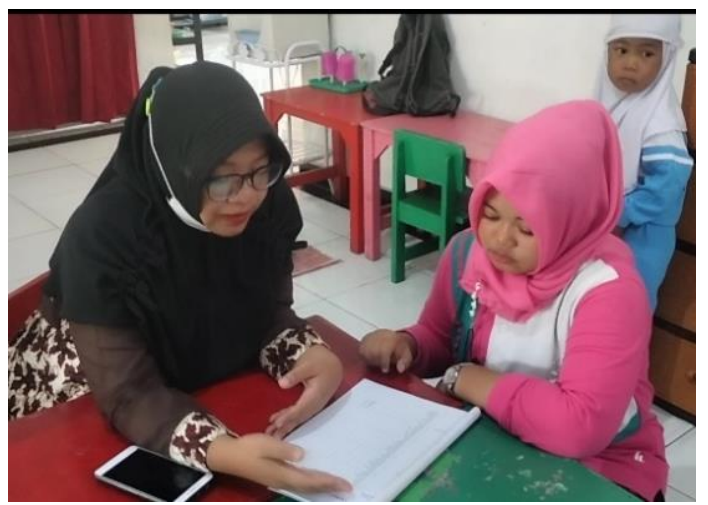

Gambar 3. Pendampingan Penyusunan Asesmen

Pada tahap evaluasi dilakukan pemaparan singkat pada setiap guru yang mengajar dikelas terhadap asesmen yang telah disediakan oleh tim pengabdi. Pada pertemuan kegiatan ini guru-guru di TK Salsa dengan didampingi oleh tim pengabdi akan melakukan real teaching untuk mengimplementasikan hasil dari kegiatan pendampingan yang telah dilakukan. Real teaching di dalam kelas dilakukan pada tanggal 7 Agustus 2021. Real Teaching dilakukan oleh 3 guru dikelas masing-masing. Real teaching dilakukan dengan menggunakan alat permainan edukatif yang telah disediakan oleh tim pengabdi dan guru akan merealisasikannya kepada anak-anak.
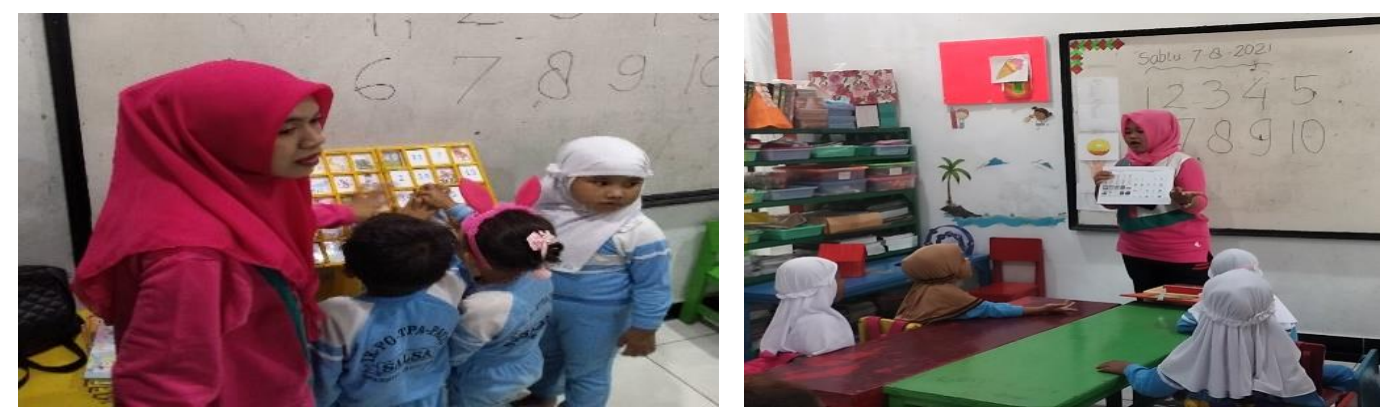

Gambar 4. Kegiatan Real Teaching penggunaan alat permainan edukatif Magic Babo

Setelah tim pengabdi mendampingi guru-guru dalam mengajar dengan meggunakan alat permainan edukatif "Magic BaBo" yang telah disediakan, tim pengabdi juga memberikan sedikit pemahaman tentang asesmen terhadap anak. Kemudia para guru mengisi asesmen tersebut sesuai dengan kemampuan anak setelah bermain "Magic Babo". 


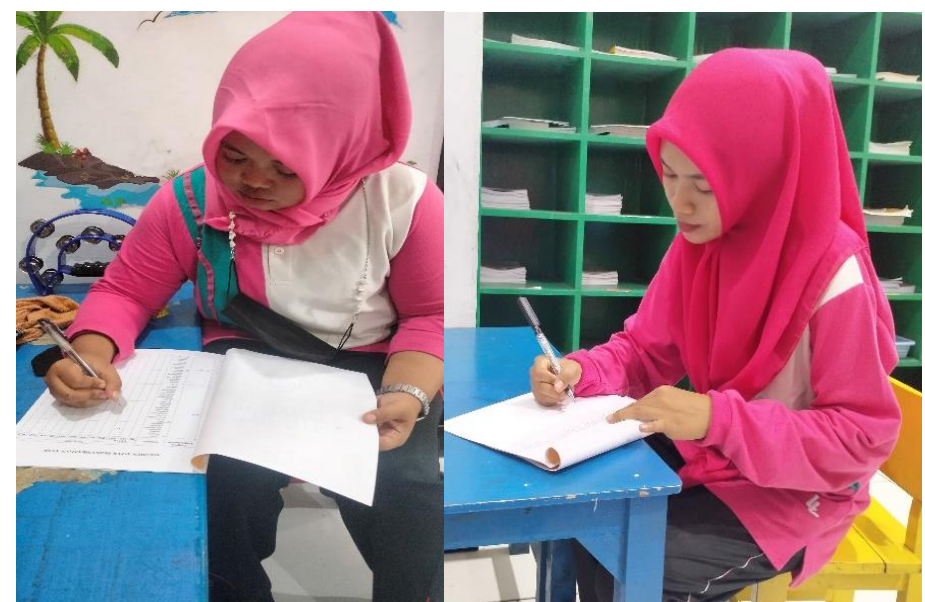

Gambar 3. Guru menyusunan Asesmen hasil Real Teaching penggunaan alat permainan edukatif Magic Babo

Berdasarkan pengamatan dan evaluasi pelaksanaan pendampingan penggunaan alat permainan edukatif Maguc Babo dan penyusunan asesmen, ada beberapa catatan sebagai berikut.

1. Pendampingan penggunaan alat permainan edukatif mendapatkan respon yang positif dari para guru TK Salsa dan pelatihan terlaksana dengan baik.

2. Peserta pendampingan memahami penggunaan alat permainana edukatif Magic Babo karena peragaan yang baik saat praktik secara langsung.

3. Peserta pendampingan mendapatkan pengetahuan dan pengalaman yang bermanfaat sehingga diharapkan pendampingan bagi para guru dapat dilaksanakan secara berkala dan terus-menerus.

4. Hasil pendampingan ini bersifat moril berupa peningkatan keterampilan guru dalam menggunakan APE Magic BABO, peningkatan pengetehuan guru dalam menyusun asesmen berbasis enam asperk perkembangan anak, hasil yang bersifat fisik adalah adanya APE Magic BABO bebrbasis enam aspek perkembangan anak usia dini yang dapat digunakan oleh guru di dalam pelaksanaan pembelajaran.

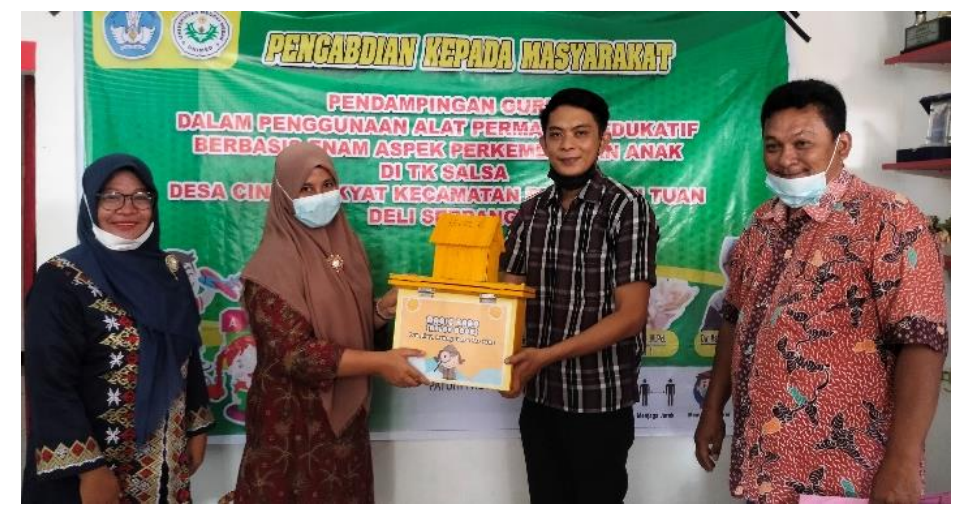

Gambar 3. Penyerahan alat permainan edukatif Magic Babo di TK Salsa Desa Cinta Rakyat 


\section{KESIMPULAN}

Kegiatan pendampingan guru dalam penggunaan alat permainan edukatif berbasis enam aspek perkembangan anak di Tk Salsa Desa Cinta Rakyat Kecamatan Percut Sei Tuan Deli Serdang telah memberikan tambahan pengetahuan dan peningkatan kompetensi guru-guru TK Salsa Desa Cinta Rakyat dalam penggunaan alat permainan edukatif dan asesmen perkembangan anak.

Kegiatan pendampingan guru dalam penggunaan alat permainan edukatif berbasis enam aspek perkembangan anak di Tk Salsa Desa Cinta Rakyat Kecamatan Percut Sei Tuan Deli Serdang telah menghasilkan luaran sebagai berikut; 1) Buku panduan penggunaan alat permainan edukatif (APE) Magic Babo. 2) Buku asesmen enam aspek perkembangan anak. 3) Video pembelajaran penggunaan APE Magic Babo.

\section{DAFTAR RUJUKAN}

Firdani, Lara. Dkk, 2011, Evaluasi Perkembangan Anak Usia Dini. Jakarta: Universitas Terbuka.

Pyle, A., Prioletta, J., \& Poliszczuk, D. (2018). The Play-Literacy Interface in Full-day Kindergarten Classrooms. Early Childhood Education Journal, 46(1), 117-127. https://doi.org/10.1007/s10643-017-0852-z

Soetjiningsih, Christiana Hari (2012). Perkembangan Anak Sejak Masa Pembuahan Sampai Dengan Kanak-Kanak Akhir. Jakarta: Prenada Media Group 